\title{
ANALISIS POTENSI SEKTORAL KABUPATEN SEMARANG
}

\author{
Jurni Hayati \\ Program Studi Ekonomi, Fakultas Ekonomi dan Sosial, Universitas Amikom Yogyakarta, \\ Indonesia \\ jurni.hayati@amikom.ac.id
}

\begin{abstract}
The purpose of this study is to identify the potential sector in Semarang Regency, Jawa Tengah Province. The data used in this study were the PDRB data of the Jawa Tengah Province and the GRDP of Semarang Regency in 20015-2019 obtained from BPS of the Jawa Tengah Province. The analytical methods used are Shifshare Analysis, it can be mapped that there are potential sectors to be developed in Semarang Regency, Jawa Tengah Province. The analysis results of Shifshare show that potential sector in Semarang Regency is transportation and warehousing sector because the sector's performance is quite good, specialized, and has a competitive advantage during the 2015-2019 period.
\end{abstract}

Keywords : Regional Developmen ${ }^{1} t$, Shifshare Analysis ${ }^{2}$, Potential Sectors ${ }^{3}$

\section{PENDAHULUAN}

Pada era otonomi daerah pembangunan daerah dilimpahkan kepada daerah masing-masing untuk menggali dan mengelola potensi-potensi yang dimiliki oleh daerahnya. Otonomi daerah ini mulai diimplementasikan sejak keluarnya UU No. 22 tahun 1999 yang telah direvisi menjadi UU No. 32 Tahun 2004 kemudian direvisi kembali UU No. 23 Tahun 2014 tentang Pemerintahan Daerah dan UU No. 25 Tahun 1999 yang telah direvisi menjadi UU No. 33 tahun 2004 tentang Perimbangan Keuangan antara Pemerintah Pusat dan Pemerintah Daerah.

Sejak diberlakukannya otonomi daerah, maka membuka peluang besar bagi pemerintah daerah untuk melakukan indentifikasi perencanaan pembangunan yang dapat mendorong perkembangan ekonomi daerah yang semakin maju. Dengan demikian pemerintah daerah dituntut untuk berperan aktif dalam membuat terobosan yang mampu meningkatkan produksi, pendapatan, dan perekonomian suatu daerah. Salah saru cara yang dapat dilakukan oleh pemerintah daerah adalah dengan mendorong kegiatan ekonomi yang potensial, baik untuk memenuhi kebutuhan daerah maupun memenuhi kebutuhan permintaan pasar.

Kabupaten Semarang adalah salah satu kabupaten di Provinsi Jawa Tengah. Ibukotanya adalah Kota Ungaran. Kabupaten ini berbatasan dengan Kota Semarang di utara; Kabupaten Demak dan Kabupaten Grobogan di timur; Kabupaten Boyolali di timur dan 
selatan; serta Kabupaten Magelang, Kabupaten Temanggung, dan Kabupaten Kendal di barat; selain itu ditengah-tengah wilayah Kabupaten Semarang terdapat Kota Salatiga dan Danau Rawa Pening. Kabupaten Semarang secara geografis sangat dekat dengan Kota Semarang dan Kota Salatiga sehingga seharusnya dapat mendorong kegiatan ekonomi di Kabupaten Semarang dibandingkan dengan kabupaten lainnya. Namun pada kenyataannya saat ini pertumbuhan ekonomi Kabupaten semarang masih lebih kecil dari pada pertumbuhan ekonomi Kabupaten Boyolali dan kabupaten Kendal (lihat Tabel 1.).

Tabel 1. Pertumbuhan Ekonomi Kabupaten/Kota Sekitar Kab. Semarang

\begin{tabular}{clcccccc}
\hline No & \multicolumn{1}{c}{ Kab/Kota } & $\mathbf{2 0 1 5}$ & $\mathbf{2 0 1 6}$ & $\mathbf{2 0 1 7}$ & $\mathbf{2 0 1 8}$ & $\mathbf{2 0 1 9}$ & Rerata \\
\hline 1 & Kab. Magelang & 5.18 & 5.39 & 5.50 & 5.28 & 5.30 & 5.33 \\
2 & Kab. Boyolali & 5.96 & 5.33 & 5.80 & 5.72 & 5.96 & 5.75 \\
3 & Kab. Grobogan & 5.96 & 4.51 & 5.85 & 5.83 & 5.37 & 5.51 \\
4 & Kab. Demak & 5.93 & 5.09 & 5.82 & 5.40 & 5.36 & 5.52 \\
5 & Kab. Semarang & 5.52 & 5.30 & 5.65 & 5.79 & 5.59 & 5.57 \\
6 & Kab. Temanggung & 5.24 & 5.02 & 5.03 & 5.13 & 5.05 & 5.09 \\
7 & Kab. Kendal & 5.21 & 5.56 & 5.78 & 5.77 & 5.69 & 5.60 \\
8 & Kota Salatiga & 5.17 & 5.27 & 5.58 & 5.84 & 5.88 & 5.55 \\
9 & Kota Semarang & 5.82 & 5.89 & 6.70 & 6.52 & 6.86 & 6.36 \\
\hline \multicolumn{5}{l}{ Sumber: $B P S$, 2020 (data diolah). } \\
\end{tabular}

Dari data tabel di atas menunjukkan bahwa pertumbuhan ekonomi di Kabupaten Semarang berada di peringkat ketiga dari delapan kabupaten/kota sekitar wilayah. Berbatasan dengan enam kabupaten dan dua kota harusnya menjadi peluang bagi pemerintah Kabupaten Semarang agar dapat meningkatkan kegiatan ekonominya sehingga pertumbuhan ekonomi meningkat dan pada akhirnya dapat meningkatkan kesejahteraan masyarakat. Dengan demikian diperlukan analisis potensi wilayah agar pemerintah Kabupaten Semarang dapat mengembangkan sektor ekonomi sesuai dengan potensi yang dimilikinya.

\section{TINJAUAN PUSTAKA}

\section{Pembangunan Ekonomi Daerah}

Pengertian pembangunan ekonomi daerah adalah suatu proses dimana pemerintah daerah dan kelompok-kelompok masyarakat mengelolah sumber daya yang ada dalam bentuk suatu pola kemitraan antara pemerintah daerah dan sektor swasta untuk menciptakan suatu lapangan kerja baru serta merangsang perkembangan kegiatan ekonomi dalam wilayah 
tersebut. Kinerja perekonomian daerah tidak memungkinkan untuk lepas dari perekonomian propinsi atau nasional (Arsyad, 2002).

Dalam upaya meningkatkan pembangunan di daerah-daerah tidak semata-mata menekan pada peranan kekuatan luar (external forces), tetapi sudah pada saatnya untuk mengutamakan pada peranan kekutan dari dalam (internal forces), yang dilakukan melalui upaya-upaya mendorong pengembangan inisiatif dan partisipasi masyarakat yang kreatif dan produktif, peningkatan kualitas dan sumberdaya manusia, pemanfaatan sumberdaya ekonomi, sosial, teknologi, dan kelembagaan untuk menunjang penciptaan lapangan kerja bagi penduduk dan masyarakat setempat (Adisasmita, 2005).

Ciri atau sifat utama suatu pembangunan yang berorientasi atau berbasis ekonomi lokal adalah menekankan kepada kebijaksanaan pembangunan pribumi (endogenous development policies) yang memanfaatkan potensi sumberdaya manusia lokal, sumberdaya institusional lokal dan sumberdaya fisik lokal. Orientasi ini menekankan pada pemberian prakarsa lokal (lokal initiatives) dalam proses pembangunan untuk menciptakan lapangan kerja baru dan mendorong peningkatan kegiatan ekonomi secara luas (Adisasmita, 2005).

\section{Teori Pertumbuhan Ekonomi}

Pertumbuhan ekonomi adalah sebagai kenaikan jangka panjang dalam kemampuan suatu negara untuk menyediakan semakin banyak jenis barang-barang ekonomi kepada penduduknya. Kemampuan ini tumbuh sesuai dengan kemajuan teknologi dan penyesuaian kelembagaan dan ideologis yang diperlukannya (Kuznets, 1955).

Terdapat tiga unsur pokok untuk meningkatkan pertumbuhan ekonomi suatu Negara (Smith, 1986):

a. Faktor sumber daya alam; SDA yang tersedia merupakan wadah yang paling mendasar dari kegiatan produksi suatu masyarakat.

b. Sumber daya manusia; perkembangan penduduk akan mendorong pertumbuhan ekonomi kerena pertumbuhan penduduk akan memperluas pasar produksi.

c. Stok capital yang ada; stok capital memegang peranan paling penting dalam menentukan cepat lambatnya proses pertumbuhan output. 
Menurut Kuznets (Budiono, 1992) pertumbuhan ekonomi dicirikan dengan 3 hal pokok, antara lain:

a. laju pertumbuhan perkapita dalam arti nyata (riil).

b. persebaran atau distribusi angkatan kerja menurut sektor kegiatan produksi yang menjadi sumber nafkahnya.

c. pola persebaran penduduk.

Pertumbuhan ekonomi merupakan hal penting di dalam kehidupan perekonomian. Laju pertumbuhan ekonomi ditandai dengan laju kenaikan pendapatan per kapita yang tinggi. Untuk mendorong terjadinya pertumbuhan ekonomi daerah perlu ditentukan prioritas pembangunan daerah (Sjafrizal, 1997). Kebijakan yang perlu dilakukan adalah mengusahakan semaksimal mungkin agar prioritas pembangunan daerah sesuai dengan potensi yang dimiliki oleh daerah bersangkutan.

\section{Penelitian Terdahulu}

Penelitian Adhitama (2012) yang berjudul "Pengembangan Sektor-sektor Ekonomi Kecamatan-kecamatan di Kabupaten Magelang. Metode analisis yang digunakan dalam penelitian ini yaitu Location Quotient (LQ), Shifshare, dan Klassen Tipologi Pendekatan Sektoral. Hasil dari penelitian tersebut adalah sektor jasa, sektor pertanian dan sektor perdagangan, hotel dan restoran di Kabupaten Magelang mendominasi sektor unggulan yang ada ditiap kecamatan di Kabupaten Magelang.

Penelitian Basuki dan Mujiraharjo (2017) yang berjudul "Analisis Sektor Unggulan Kabupaten Sleman” dengan Metode Shifshare dan Location Quotient. Hasil penelitian menunjukkan bahwa sektor unggulan di Kabupaten Sleman ada empat sektor yaitu sektor kontruksi, sektor transportasi dan pergudangan, sektor real estate, dan sektor jasa perusahaan. Sedangkan sektor terbelakang ada lima sektor yaitu sektor pertanian, kehutanan, dan perikanan, sektor pertambangan dan penggalian, sektor pengadaan listrik dan gas, sektor perdagangan besar dan eceran; reparasi mobil dan sepeda motor, sektor administrasi pemerintahan, pertahanan, dan jaminan sosial wajib.

Penelitian Radhi dan Hariningsih (2017) tentang kontribusi sektor unggulan terhadap PDRB Kabupaten Kulon Progo dengan menggunakan alat Location Quotient, Shiftshare, Boston Consulting Group. Hasil penelitian menunjukkan bahwa Kabupaten Kulon Progo 
memiliki empat sektor basis yaitu sektor pertanian, sektor pertambangan dan penggalian, sektor industri pengolahan, dan sektor jasa-jasa. Dari keempat sektor basis, yang telah menghasilkan kontribusi PDRB tinggi dan pertumbuhan PDRB yang tinggi adalah sektorjasa-jasa. Sedangkan sektor pertanian masih memiliki tingkat pertumbuhan yang rendah. Untuk sektor pertambangan dan penggalian, meskipun meiliki tingkat pertumbuhan yang tinggi tetapi kontribusi terhadap PDRB Kabupaten Kulon Progo masih rendah. Demikian juga untuk sektor industri pengolahan, meskipun merupakan sektor basis, tetapi tingkat pertumbuhannya masih rendah dan tingkat kontribusinya terhadap PDRB juga masih rendah. Sedangkan berdasarkan analisis Shift-Share, disimpulkan bahwa sektor konstruksi menduduki nilai prosentase pertumbuhan Prosentase pertumbuhan positif terbesar, rasio produksi terbesar, dan nilai Pergeseran Bersih terbesar di Kabupaten Kulon Progo.

\section{METODE PENELITIAN}

\section{Jenis Penelitian}

Penelitian ini menggunakan analisis deskriptif kuantitatif. Menurut Gujarati (2010) analisis deskriptif disusun berdasarkan data sekunder, jurnal, artikel, dan hasil-hasil penelitian yang berhubungan dengan permasalahan. Analisis kuantitatif dari fenomena ekonomi yang sebenarnya (aktual) yang didasarkan pada pengembangan yang bersamaan dari teori dan pengamatan, dihubungkan dengan metode inferensi yang sesuai.

\section{Jenis dan Sumber Data}

Jenis data yang digunakan untuk penelitian ini adalah data sekunder. Data yang digunakan penelitian ini adalah data PDRB Kabupaten Semarang dan data PDRB Provinsi Jawa Tengah dari tahun 2015-2019. Data diperoleh dari BPS Provinsi Jawa Tengah dan instansi terkait lainnya.

\section{Metode Analisis Data}

Untuk melihat potensi sektoral Kabupaten Semarang digunakan analisis Shifshare. Analisis shifshare dilakukan untuk mengetahui kinerja dan daya saing sektor ekonomi wilayah studi dibandingkan wilayah referensi. Kemudian dilakukan analisis terhadap penyimpangan yang terjadi sebagai hasil perbandingan tersebut. Bila penyimpangan tersebut positif, maka dikatakan sektor ekonomi wilayah studi berpotensi untuk 
dikembangkan atau sebaliknya. Berikut formulasi analisis shiftshare yang digunakan pada penelitian ini:

1. Untuk melihat dampak nyata pertumbuhan ekonomi wilayah studi (national growht effect) terhadap sektor-sektor ekonomi di wilayah studi itu sendiri digunakan analisis Dij.

Formulasi perhitungan $\mathrm{Dij}: \mathrm{Dij}=\mathrm{Nij}+\mathrm{Mij}+\mathrm{Cij}$

2. Untuk melihat pengaruh pertumbuhan ekonomi wilayah referensi (proportional shift) terhadap pertumbuhan ekonomi wilayah studi digunakan analisis Nij.

Formulasi perhitungan Nij: $\mathrm{Nij}=\mathrm{Eij} \times \mathrm{Rn}$

3. Untuk melihat pengaruh bauran industri (industry mix) antara wilayah studi dan wilayah referensi digunakan analisis Mij.

Formulasi perhitungan Mij: $\mathrm{Mij}=\operatorname{Eij}(\mathrm{Rin}-\mathrm{Rn})$

4. Untuk melihat perbandingan keunggulan kompetitif (differential shift) wilayah studi dengan wilayah referensi digunakan analisis $\mathrm{Cij}$.

Formulasi perhitungan $\mathrm{Cij}: \mathrm{Cij}=\mathrm{Eij}(\mathrm{Rij}-\mathrm{Rin})$

Keterangan:

Eij= PDRB sektor i wilayah studi

Rij= tingkat pertumbuhan sektor i wilayah studi

Rin= tingkat pertumbuhan sektor $\mathrm{i}$ wilayah referensi

$\mathrm{Rn}=$ tingkat pertumbuhan ekonomi wilayah referensi

\section{HASIL DAN PEMBAHASAN}

\section{Analisis Shifshare Dij}

Analisis Dij digunakan untuk melihat dampak nyata pertumbuhan ekonomi di Kabupaten Semarang (national growht effect) terhadap sektor-sektor ekonomi di Kabupaten Semarang itu sendiri.

Tabel 2. Hasil Perhitungan Shiftshare Dij Tahun 2015-2019:

\begin{tabular}{clccccc}
\hline NO & PDRB Lapangan Usaha & $\mathbf{2 0 1 5}$ & $\mathbf{2 0 1 6}$ & $\mathbf{2 0 1 7}$ & $\mathbf{2 0 1 8}$ & $\mathbf{2 0 1 9}$ \\
\hline 1 & $\begin{array}{l}\text { Pertanian,Kehutanan \& } \\
\text { Perikanan }\end{array}$ & 17250070.37 & 9979100.848 & 9701203.916 & 10228554.65 & 4783047.284 \\
2 & $\begin{array}{l}\text { Pertambangan dan } \\
\text { Penggalian }\end{array}$ & 157859.376 & 317932.1376 & 334886.3505 & 395565.858 & 344809.3792 \\
3 & Industri Pengolahan & 47079224.14 & 59184531.66 & 52308103.59 & 67528364.87 & 96190568.72 \\
\hline 4 & Pengadaan Listrik dan Gas & 88060.9761 & 123493.9552 & 43044.5124 & 226305.4619 & 132096.6107 \\
\hline
\end{tabular}




\begin{tabular}{|c|c|c|c|c|c|c|}
\hline NO & PDRB Lapangan Usaha & 2015 & 2016 & 2017 & 2018 & 2019 \\
\hline 5 & $\begin{array}{l}\text { Pengadaan Air, } \\
\text { Pengelolaan Sampah, } \\
\text { Limbah dan Daur Ulang }\end{array}$ & 45531.74 & 54754.3655 & 179842.32 & 142448.4919 & 119514.771 \\
\hline 6 & Konstruksi & 25032935.95 & 23352863.01 & 31707061.25 & 27990141.28 & 12011716.86 \\
\hline 7 & $\begin{array}{l}\text { Perdagangan Besar dan } \\
\text { Eceran; Reparasi Mobil } \\
\text { dan Sepeda Motor }\end{array}$ & 14860155.7 & 18664338.16 & 23529825.47 & 24221445.22 & 24599070.2 \\
\hline 8 & $\begin{array}{l}\text { Transportasi dan } \\
\text { Pergudangan }\end{array}$ & 5829498.223 & 2790987.93 & 5002222.7 & 6101130.424 & 7421804.512 \\
\hline 9 & $\begin{array}{l}\text { Penyediaan Akomodasi } \\
\text { dan Makan Minum }\end{array}$ & 6306539.875 & 5213610.542 & 6805165.232 & 8585570.519 & 9583597.153 \\
\hline 10 & Informasi dan Komunikasi & 10897013.81 & 10166208.79 & 19502521.7 & 18947982.13 & 16345309.87 \\
\hline 11 & $\begin{array}{l}\text { Jasa Keuangan dan } \\
\text { Asuransi }\end{array}$ & 8200504.813 & 8769340.34 & 6245867.445 & 4615136.88 & 4402014.528 \\
\hline 12 & Real Estate & 7183727.438 & 6467051.27 & 7170248.012 & 6740081.096 & 6409906.162 \\
\hline 13 & Jasa Perusahaan & 1278307.015 & 1388670.609 & 1377754.312 & 1585847.452 & 1830652.98 \\
\hline 14 & $\begin{array}{l}\text { Administrasi } \\
\text { Pemerintahan, Pertahanan } \\
\text { dan Jaminan Sosial }\end{array}$ & 4501825.07 & 1774042.025 & 2186834.842 & 4343782.802 & 2351570.739 \\
\hline 15 & Jasa Pendidikan & 7402869.59 & 7845335.39 & 9026989.567 & 8761126.059 & 9186505.036 \\
\hline 16 & $\begin{array}{l}\text { Jasa Kesehatan dan } \\
\text { Kegiatan Sosial }\end{array}$ & 1445998.353 & 1880163.89 & 2177675.256 & 2239153.207 & 1710306.841 \\
\hline 17 & Jasa lainnya & 1877704.902 & 3136097.726 & 5229891.068 & 4563559.592 & 4330029.662 \\
\hline
\end{tabular}

Sumber: BPS, 2020 (data diolah).

Dari tabel 1 diatas dapat dilihat bahwa ada kenaikan kinerja di semua sektor di Kabupaten Semarang, hal tersebut ditunjukkan dari hasil perhitungan Dij $>0$ (bernilai positif). Meningkatnya kinerja tersebut dikarenakan adanya pertumbuhan di Kabupaten Semarang. Kenaikan kinerja di sektor industri pengolahan, perdagangan besar dan eceran, reparasi mobil dan sepeda motor, jasa perusahaan trennnya meningkat dari tahun ke tahun. Namun kenaikan kinerja di sektor yang lainnya relatif berfluktuatif sepanjang tahun 2015-2019.

Meningkatnya kinerja di sektor industri pengolahan disebab karena terus berkembangnya industry di Kenaikan kinerja di sektor industri pengolahan. Sektor perdagangan besar dan eceran meningkat karena letak Kabupaten Semarang yang strategis di kelilingi enam kabupaten dan dua kota sehingga sering dijadikan tempat transit para pelaku perjalanan. Sektor jasa perusahaan trennya juga terus meningkat, hal ini disebabkan adanya pergeseran struktur ekonomi di Kabupaten Semarang, misalnya berkembangnya jasa ojek online, toko online, dan lain-lain.

\section{Analisis Shiftshare Nij}

Analisis Nij digunakan untuk melihat pengaruh pertumbuhan ekonomi Propinsi Jawa Tengah (proportional shift) terhadap pertumbuhan ekonomi Kabupaten Semarang. 
Tabel 3. Hasil Perhitungan Shiftshare Nij Tahun 2015-2019

\begin{tabular}{|c|c|c|c|c|c|c|}
\hline NO & PDRB Lapangan Usaha & 2015 & 2016 & 2017 & 2018 & 2019 \\
\hline 1 & $\begin{array}{l}\text { Pertanian,Kehutanan \& } \\
\text { Perikanan }\end{array}$ & 17956898.55 & 17750651.42 & 18284940.01 & 18973043.76 & 19612752.77 \\
\hline 2 & $\begin{array}{l}\text { Pertambangan dan } \\
\text { Penggalian }\end{array}$ & 359466.8958 & 361108.2034 & 378718.5724 & 402010.1963 & 428055.8061 \\
\hline 3 & Industri Pengolahan & 60970057.89 & 61498105.51 & 64268374.52 & 68236336.47 & 74484023.35 \\
\hline 4 & Pengadaan Listrik dan Gas & 203064.9228 & 201249.4623 & 203923.3343 & 217099.4264 & 228431.0563 \\
\hline 5 & $\begin{array}{l}\text { Pengadaan Air, } \\
\text { Pengelolaan Sampah, } \\
\text { Limbah dan Daur Ulang }\end{array}$ & 124418.2283 & 122263.2085 & 131350.4333 & 139684.8681 & 148709.9876 \\
\hline 6 & Konstruksi & 21144979.52 & 21460949.05 & 23061619.59 & 24665922.97 & 25799563.4 \\
\hline 7 & $\begin{array}{l}\text { Perdagangan Besar dan } \\
\text { Eceran; Reparasi Mobil } \\
\text { dan Sepeda Motor }\end{array}$ & 18168354.62 & 18375124.29 & 19578244.02 & 20961789.22 & 22643793.03 \\
\hline 8 & $\begin{array}{l}\text { Transportasi dan } \\
\text { Pergudangan }\end{array}$ & 3520321.729 & 3520541.983 & 3774003.984 & 4107455.463 & 4559754.004 \\
\hline 9 & $\begin{array}{l}\text { Penyediaan Akomodasi } \\
\text { dan Makan Minum }\end{array}$ & 4827171.131 & 4894086.921 & 5239502.846 & 5707619.853 & 6302843.525 \\
\hline 10 & Informasi dan Komunikasi & 6262197.288 & 6505640.68 & 7420870.219 & 8383638.72 & 9362011.29 \\
\hline 11 & $\begin{array}{l}\text { Jasa Keuangan dan } \\
\text { Asuransi }\end{array}$ & 5297488.054 & 5510935.779 & 5833866.383 & 6120872.971 & 6474577.947 \\
\hline 12 & Real Estate & 5072343.388 & 5188877.952 & 5553113.029 & 5939602.785 & 6389393.755 \\
\hline 13 & Jasa Perusahaan & 717258.9507 & 755121.4907 & 823305.8788 & 907549.7595 & 1016270.273 \\
\hline 14 & $\begin{array}{l}\text { Administrasi } \\
\text { Pemerintahan, Pertahanan } \\
\text { dan Jaminan Sosial }\end{array}$ & 4457068.4 & 4370480.635 & 4492086.692 & 4751329.337 & 4971940.161 \\
\hline 15 & Jasa Pendidikan & 5213605.173 & 5388440.058 & 5838812.171 & 6323555.894 & 6915590.004 \\
\hline 16 & $\begin{array}{l}\text { Jasa Kesehatan dan } \\
\text { Kegiatan Sosial }\end{array}$ & 1055080.853 & 1103578.139 & 1210525.911 & 1330212.8 & 1444188.273 \\
\hline 17 & Jasa lainnya & 1872606.571 & 1949808.867 & 2198403.684 & 2438053.599 & 2703208.752 \\
\hline
\end{tabular}

Sumber: BPS, 2020 (data diolah).

Dari data tabel diatas menunjukkan bahwa ada pengaruh pertumbuhan sektor i Propinsi Jawa Tengah terhadap pertumbuhan sektor i di Kabupaten Semarang. Hal ini menunjukkan bahwa pertumbuhan ekonomi di Kabupaten Semarang masih sangat bergantung pada pertumbuhan ekonomi Propinsi Jawa Tengah.

Pertumbuhan ekonomi Provinsi Jawa Tengah membaik di dorong oleh pesatnya peningkatan investasi dan konsumsi rumah tangga. Sementara dari sisi lapangan usaha peningkatan pertumbuhan terutama berasal dari lapangan usaha pertanian, kehutanaan, serta lapangan usaha perdagangan besar. Perbaikan ekonomi juga didukung oleh terjaganya stabilitas harga yang dicerminkan dengan meningkatnya pertumbuhan per sektor di setiap tahunnya.

\section{Analisis Shiftshare Mij}


Analisis Mij digunakan untuk melihat pengaruh bauran industri (industry mix) antara

Kabupaten Semarang dan Propinsi Jawah Tengah.

Tabel 4. Hasil Perhitungan Shiftshare Mij Tahun 2015-2019

\begin{tabular}{|c|c|c|c|c|c|c|}
\hline NO & PDRB Lapangan Usaha & 2015 & 2016 & 2017 & 2018 & 2019 \\
\hline 1 & $\begin{array}{l}\text { Pertanian,Kehutanan \& } \\
\text { Perikanan }\end{array}$ & 432473.8354 & -10306711.6 & -11951089.13 & -9593846.995 & -14671394.93 \\
\hline 2 & $\begin{array}{l}\text { Pertambangan dan } \\
\text { Penggalian }\end{array}$ & -58825.5629 & 944959.5435 & -11000.52747 & -216067.1341 & -162189.951 \\
\hline 3 & Industri Pengolahan & -8461644.012 & -13456887.04 & -11372810.3 & -12287844.76 & -3001310.521 \\
\hline 4 & $\begin{array}{l}\text { Pengadaan Listrik dan } \\
\text { Gas }\end{array}$ & -112601.2941 & -26156.71333 & -1499.328849 & 2337.659184 & 2722.418387 \\
\hline 5 & $\begin{array}{l}\text { Pengadaan Air, } \\
\text { Pengelolaan Sampah, } \\
\text { Limbah dan Daur Ulang }\end{array}$ & -87215.56816 & -71634.29295 & 31282.91376 & -11123.70654 & -27355.86249 \\
\hline 6 & Konstruksi & 2086261.451 & 5219934.635 & 8202943.049 & 3562048.934 & -2214387.081 \\
\hline 7 & $\begin{array}{l}\text { Perdagangan Besar dan } \\
\text { Eceran; Reparasi Mobil } \\
\text { dan Sepeda Motor }\end{array}$ & -4586016.466 & 1467063.062 & 2285397.346 & 1848281.559 & 2380583.682 \\
\hline 8 & $\begin{array}{l}\text { Transportasi dan } \\
\text { Pergudangan }\end{array}$ & 1433838.042 & -223344.489 & 747745.8716 & 1734781.695 & 2592578.76 \\
\hline 9 & $\begin{array}{l}\text { Penyediaan Akomodasi } \\
\text { dan Makan Minum }\end{array}$ & 1166121.469 & 945062.1172 & 1182538.203 & 3085740.026 & 4339442.189 \\
\hline 10 & Informasi dan Komunikasi & 4656612.92 & 3792732.288 & 11305142.6 & 11193578.85 & 10741063.25 \\
\hline 11 & $\begin{array}{l}\text { Jasa Keuangan dan } \\
\text { Asuransi }\end{array}$ & 2077368.351 & 3695863.438 & -99112.94115 & -1992277.198 & -2277537.506 \\
\hline 12 & Real Estate & 1970598.858 & 1543723.833 & 1287143.435 & 307316.4918 & 143179.9607 \\
\hline 13 & Jasa Perusahaan & 397085.5751 & 773545.0126 & 541438.3523 & 714843.3323 & 963256.3101 \\
\hline 14 & $\begin{array}{l}\text { Administrasi } \\
\text { Pemerintahan, Pertahanan } \\
\text { dan Jaminan Sosial }\end{array}$ & -126773.7583 & -2397542.56 & -2296039.17 & -1548764.449 & -1563505.242 \\
\hline 15 & Jasa Pendidikan & 1986347.7 & 2159354.056 & 1903699.545 & 2921281.759 & 2783047.059 \\
\hline 16 & $\begin{array}{l}\text { Jasa Kesehatan dan } \\
\text { Kegiatan Sosial }\end{array}$ & 220414.0015 & 969895.46 & 769967.1821 & 876276.8529 & 349586.7303 \\
\hline 17 & Jasa lainnya & -773714.3463 & 1259388.5 & 1554333.27 & 1903463.34 & 1803573.211 \\
\hline
\end{tabular}

Sumber: BPS, 2020 (data diolah).

Dari tabel diatas dapat diketahui ada beberapa sektor yang terspesialisasi di Kabupaten Semarang. Sektor yang terspesialisasi tersebut dapat mempengaruhi sektor-sektor yang lain di Kabupaten Semarang. Sektor dapat menjadi sektor yang terspesialisasi karena ada aktivitas-aktivitas yang berhubungan antar sektor di Kabupaten Semarang dan tumbuh lebih cepat dari pada sektor yang sama di Propinsi Jawa Tengah. Sedangkan sektor yang tidak terspesialisasi maka sektor tersebut tidak dapat mempengaruhi sektor-sektor yang lain di Kabupaten Semarang. Sektor tidak terspesialisasi karena tidak ada aktivitas- 
aktivitas yang berhubungan antar sektor di Kabupaten Semarang dan tumbuh lebih lambat dari pada sektor yang sama di Propinsi Jawa Tengah.

\section{Analisis Shiftshare Cij}

Analisis Cij digunakan untuk melihat perbandingan keunggulan kompetitif (differential shift) di Kabupaten Semarang dengan Propinsi Jawa Tengah.

Tabel 5. Hasil Perhitungan Shiftshare Cij Tahun 2015-2019

\begin{tabular}{|c|c|c|c|c|c|c|}
\hline NO & PDRB Lapangan Usaha & 2015 & 2016 & 2017 & 2018 & 2019 \\
\hline 1 & $\begin{array}{l}\text { Pertanian,Kehutanan \& } \\
\text { Perikanan }\end{array}$ & -1139302.011 & 2535161.028 & 3367353.032 & 849357.8878 & -158310.5532 \\
\hline 2 & $\begin{array}{l}\text { Pertambangan dan } \\
\text { Penggalian }\end{array}$ & -142781.9569 & -988135.6094 & -32831.69445 & 209622.7958 & 78943.52412 \\
\hline 3 & Industri Pengolahan & -5429189.744 & 11143313.19 & -587460.6338 & 11579873.16 & 24707855.9 \\
\hline 4 & Pengadaan Listrik dan Gas & -2402.65253 & -51598.79372 & -159379.493 & 6868.376296 & -99056.86399 \\
\hline 5 & $\begin{array}{l}\text { Pengadaan Air, Pengelolaan } \\
\text { Sampah, Limbah dan Daur } \\
\text { Ulang }\end{array}$ & 8329.079831 & 4125.44999 & 17208.97296 & 13887.3303 & -1839.354147 \\
\hline 6 & Konstruksi & 1801694.983 & -3328020.678 & 442498.6102 & -237830.6206 & -11573459.46 \\
\hline 7 & $\begin{array}{l}\text { Perdagangan Besar dan } \\
\text { Eceran; Reparasi Mobil dan } \\
\text { Sepeda Motor }\end{array}$ & 1277817.549 & -1177849.196 & 1666184.098 & 1411374.441 & -425306.5092 \\
\hline 8 & $\begin{array}{l}\text { Transportasi dan } \\
\text { Pergudangan }\end{array}$ & 875338.4512 & -506209.5644 & 480472.8437 & 258893.2666 & 269471.7479 \\
\hline 9 & $\begin{array}{l}\text { Penyediaan Akomodasi dan } \\
\text { Makan Minum }\end{array}$ & 313247.2753 & -625538.4962 & 383124.1836 & -207789.3599 & -1058688.561 \\
\hline 10 & Informasi dan Komunikasi & -21796.39402 & -132164.1763 & 776508.8821 & -629235.4409 & -3757764.669 \\
\hline 11 & Jasa Keuangan dan Asuransi & 825648.4072 & -437458.8772 & 511114.0036 & 486541.1079 & 204974.0873 \\
\hline 12 & Real Estate & 140785.192 & -265550.5149 & 329991.5489 & 493161.8189 & -122667.5535 \\
\hline 13 & Jasa Perusahaan & 163962.489 & -139995.8948 & 13010.0809 & -36545.64021 & -148873.6027 \\
\hline 14 & $\begin{array}{l}\text { Administrasi Pemerintahan, } \\
\text { Pertahanan dan Jaminan } \\
\text { Sosial }\end{array}$ & 171530.4292 & -198896.0497 & -9212.680615 & 1141217.914 & -1056864.179 \\
\hline 15 & Jasa Pendidikan & 202916.7178 & 297541.2768 & 1284477.851 & -483711.5939 & -512132.0272 \\
\hline 16 & $\begin{array}{l}\text { Jasa Kesehatan dan Kegiatan } \\
\text { Sosial }\end{array}$ & 170503.4983 & -193309.7085 & 197182.163 & 32663.55431 & -83468.16222 \\
\hline 17 & Jasa lainnya & 778812.6779 & -73099.64036 & 1477154.114 & 222042.6535 & -176752.2998 \\
\hline
\end{tabular}

Data pada tabel di atas memberikan gambaran bahwa dari hasil perhitungan $\mathrm{Cij}$ tahun 2015-2019 sektor yang memiliki keunggulan kompetitif di Kabupaten Semarang sering berubah-ubah. Adanya perubahan keunggulan kompetitif pada sektor-sektor ekonomi di Kabupaten Semarang disebabkan karena adanya pertumbuhan yang berfluktuatif jika dibandingkan dengan pertumbuhan Propinsi Jawa Tengah. Sektor akan menjadi sektor 
yang memiliki keunggulan kompetitif jika sektor di Kabupaten Semarang tersebut tumbuh lebih cepat dari pada Propinsi Jawa Tengah. Jika sektor tidak memiliki keunggulan kompetitif berarti sektor tersebut tumbuh lebih lambat jika dibandingkan Provinsi Jawa Tengah.

Untuk sektor yang memiliki keunggulan kompetitif perlu terus dikembangkan karena pengaruhnya cukup besar terhadap pertumbuhan ekonomi di Kabupaten Semarang dan pada akhirnya dapat meningkatkan pendapatan masyarakat. Misalnya pengembangan dari sisi sektor transportasi dan pergudangan sehingga sektor tersebut mengalami kenaikan pada periode 2018-2019, peningkatan ini juga didukung dengan adanya penambahan rute baru dan juga alat transportasi seperti gerbong atau pesawat, pertumbuhan sektor transportasi dan pergudangan akan terus berlanjut dengan membaiknya manajemen dan juga infrastruktur.

\section{KESIMPULAN}

Analisis Shifshare dapat memberikan gambaran pergeseran dan peranan setiap sektor di Kabupaten Semarang. Berdasarkan analisis Dij pada tahun 2015-2019 mayoritas terdapat kenaikan kinerja di semua sektor Kabupaten Semarang. Berdasarkan analisis Nij pada tahun 2015-2019 mayoritas ada pengaruh pertumbuhan sektor i di Propinsi Jawa Tengah terhadap pertumbuhan sektor i di Kabupaten Semarang. Berdasarkan analisis Mij pada tahun 20152019 keadaannya bercampur, ada sektor yang terspesialisasi dan ada juga sektor yang tidak terspesialisasi, hal ini dikarenakan tidak semua aktivitas-aktivitas antar sektor di Kabupaten Semarang saling berhubungan. Berdasarkan analisis Cij pada tahun 2015-2019, sektor yang memiliki keunggulan kompetitif di Kabupaten Semarang tidak menetap, hal ini menunjukkan bahwa pertumbuhan per sektor selama tahun 2015-2019 di Kabupaten Semarang berfluktuatif. Dari keempat analisis tersebut sektor yang sangat potensial untuk di kembangkan adalah sektor transportasi dan pergudangan karena kinerja sektor tersebut cukup baik, terspesialisasi, dan memiliki keunggulan kompetitif selama periode 2015-2019.

\section{KETERBATASAN DAN REKOMENDASI}

Keterbatasan penelitian ini dari sisi alat analisis, alat analisis yang digunakan hanya satu, yaitu analisis Shifshare. Kemudian data penelitian yang digunakan masih sedikit, hanya 
selama lima tahun. Saran untuk penelitian berikutnya ada penambahan alat analisis dan ada penambahan data sehingga hasil analisis akan menjadi lebih komprehensif.

\section{DAFTAR PUSTAKA}

Adisasmita, R. (2005). Dasar-dasar Ekonomi Wilayah. Yogyakarta: Graha Ilmu.

Arsyad, L. (2002). Pengantar Perencanaan Ekonomi Daerah. Yogyakarta: BPFE Universitas Gadjah Mada.

Arsyad, L. (2005). Pengantar Perencanaan Pengembangan Ekonomi Daerah. Yogyakarta: BPFE Universitas Gadjah Mada.

Adhitama, Rifki. (2012). Pengembangan sektor-sektor ekonomi di tiap kecamatan di Kabupaten Magelang. Economics Development Analysis Journal 1 (2).

Badan Pusat Statistik. (2019). PDRB Kabupaten dan Kota di Provinsi Jawa Tengah. BPS Yogyakarta: Yogyakarta.

Basuki, Mahmud dan Mujiraharjo, Febri Nugroho. (2017). Analisis Sektor Unggulan Kabupaten Sleman dengan Metode Shifshare dan Location Quotient, Jurnal Sains, Teknologi dan Industri, Vol. 15 (1), Hal. 52-60.

Boediono. (1992). Teori Pertumbuhan Ekonomi. Yogyakarta: BPFE Universitas Gadjah Mada.

Gujarati, D.N. (2010). Basic Econometrics. New York: The McGraw-Hill Companies.

Hadhi dan Hariningsih. (2017). Kontribusi Sektor Unggulan Terhadap PDRB Kabupaten Kulon Progo, Jurnal Bisnis Teori dan Implementasi, Vol. 8 (1), Hal. 19-35.

Kuznets, Simon. (1955). Economic Growth and Income Inequality. The American Economic Review. Vol. 45 (1). Hal. 1-28.

Smith, B.C. (1986). Decentralization: The Territorial Dimension of The State. Journal of Political Science Vol. 38, Hal. 194-96.

Sjafrizal. (1997). Pertumbuhan dan Ketimpangan Regional Wilayah Indonesia Bagian Barat. Prisma. Yogyakarta: LP3ES. 